\title{
Lusioersily
}

\section{How User-centric Innovation is Affecting Stakeholder Marketing Strategies: Exploratory Findings from the Music Industry}

Gamble, J., McAdam, R., \& Brennan, M. (2018). How User-centric Innovation is Affecting Stakeholder Marketing Strategies: Exploratory Findings from the Music Industry. European Management Review, 16, 1175-1193. https://doi.org/10.1111/emre.12326

Link to publication record in Ulster University Research Portal

\section{Published in:}

European Management Review

Publication Status:

Published online: 03/09/2018

DOI:

10.1111/emre.12326

\section{Document Version}

Author Accepted version

\section{General rights}

Copyright for the publications made accessible via Ulster University's Research Portal is retained by the author(s) and / or other copyright owners and it is a condition of accessing these publications that users recognise and abide by the legal requirements associated with these rights.

\section{Take down policy}

The Research Portal is Ulster University's institutional repository that provides access to Ulster's research outputs. Every effort has been made to ensure that content in the Research Portal does not infringe any person's rights, or applicable UK laws. If you discover content in the Research Portal that you believe breaches copyright or violates any law, please contact pure-support@ulster.ac.uk. 


\begin{abstract}
This paper empirically explores how user-centric innovation (UCI) in the music industry is affecting how key stakeholder groups are approaching and developing their marketing (and associated management) strategies. The three-stage interview-based research methodology consisted of 52 semi-structured indepth interviews with UCI experts and artist managers, as well as representatives from major record labels. The findings make four substantial contributions to theory and practice in the interrelated fields of UCI, marketing and the music industry. First, they provide practical and pragmatic insights for industry practitioners on how different UCI marketing approaches are affecting their management strategies. Second, they take steps towards answering many of the identified gaps in research and knowledge relating to the concept of UCI. Third, they present theoretical models as a foundation for which new UCI marketing theory can be built upon. Last, they offer directions for future research to advance our empirical findings.
\end{abstract}




\section{Introduction}

This paper empirically explores the role of user centric innovation (UCI) as a catalyst for marketingrelated management strategies within the entertainment industry. Goltz et al. (2015: 161) have recently stated that "firms in the digital entertainment field have furthered this trend [of consumer involvement] by outsourcing the innovation process to their networks of consumers". Within this broad field, the current paper will focus on the music industry, in which turbulent industry changes and the involvement of multiple users at various stages of the innovation process make it an appropriate and useful context for exploring UCI. Scholars have recently suggested that business model innovation should aim to fulfil a marketing role by uncovering new opportunities to meet consumer needs and maintain competitiveness (Ghezzi et al., 2015; Najmaei, 2014; Sinfield et al., 2012). Within the innovation literature relating to these firms, UCI has emerged as a key concept concerning innovation pull at multiple stages of the production process (Bogers et al., 2010; Herstatt and Schweisfurth, 2014; Hienerth, 2006). Here, the organisation promotes or facilitates participation and contributions from the end consumer throughout the innovation process (Brabham et al., 2014; Di Gangi and Wasko, 2009; Faulkner and Runde, 2009). Such user interactions vary in terms of degree of involvement and control from the consumers. Examples include: crowdsourced activity such as crowdfunding; viral marketing; sponsored user-generated branding; user-generated content (UGC); vigilante marketing; and 'prosumer' marketing or consumerdriven marketing campaigns (CMCs) (Bampo et al., 2008; Gamble and Gilmore, 2013; Konczal, 2008; Muñiz and Schau, 2007).

UCI is not a new concept; it was initially discussed by von Hippel in the 1970s (Bogers et al., 2010; Herstatt and Schweisfurth, 2014; Von Hippel, 1976). However, its significance for management theory and practice is still evident in the contemporary literature, as additional radical types of innovation are being pursued due to rapidly evolving consumer requirements (Baldwin et al., 2006). They are also arguably being pursued due to more interactive marketing approaches involving customer interaction 
(Wright et al., 2012), in addition to the diversification of technology services and platforms that can enable customer input (Ardito et al., 2015; Laursen and Salter, 2006; Sawhney et al., 2005; Schildhauer and Voss, 2014). The literature suggests that a positive approach to UCI would prove most beneficial for firms in terms of return on investment, marketing and innovativeness. This is based on the provision that they consider a number of key influencing factors relating to strategic management, resource allocation and creative freedom (Di Gangi and Wasko, 2009; Franke et al., 2016; Hienerth and Lettl, 2011). The implications of UCI are more far-reaching than merely the immediate firm; recent studies suggest that they can also affect user communities in terms of both unity and disruption (Gamble et al., 2016), as well as other important facets such as the broader community (Hienerth and Lettl, 2011) and product life cycles (Parmentier and Mangematin, 2014).

Arvidsson (2008) advises that the inclination towards UCI will almost certainly continue to rise in importance in future, in view of the global reach of Internet access and the continuing contraction of the division between non-digital and digital products and services. This standpoint is defended by Berthon et al. (2007) who cite a positive relationship between the augmentation in product digitisation / interconnectivity and the enhancement in aptitude for consumer contributions. Fuller (2006) has also proposed that users represent a promising supply of forthcoming innovation in consequence of past, present and future actions: their preceding innovation endeavours; their present innovation capacities; and their compliance with future commitments. Numerous scholars are now conceding that users and their communities will play a progressively more important position in innovation across various industries and markets (Hau and Kang, 2016; Norman and Verganti, 2014; Payne et al., 2009; Piller et al., 2010). It has also been suggested that UCIs have developed into an essential strategy for firms in relation to their sustainability (Desouza et al., 2008); innovation progression (Greer and Lei, 2012; Janssen and Dankbaar, 2008); closer consumer relations (Jespersen and Buck, 2010); and achieving best practice (Enkel et al., 2005). 
The preceding discussion highlights the imperative and applicable nature of UCI in the current business environment. It also underscores its inextricable correlation to the varying technological backgrounds in which it has been examined. In spite of this interest, the phenomenon of UCI is not well understood (Bogers et al., 2010; J. Q. Dong and Wu, 2015) nor employed in either policy or industry (Franke et al., 2016; Hienerth and Lettl, 2011; S. K. Shah and Tripsas, 2007). There has been a lack of empirical research concerning UCI in practice (Baldwin et al., 2006; Di Gangi and Wasko, 2009; Faulkner and Runde, 2009; Hienerth, 2006; Morrison et al., 2000). Continuing debate regarding the managerial purpose of UCI, and the reality that it has still not been broadly established and applied to legitimate management strategies, provokes critical questions about our present understanding of this concept. Specifically, it is largely unknown how UCI is affecting key management strategy areas such as marketing at the organisational level, especially for stakeholders within dynamic and shifting industries such as the creative and digital industries. Consequently, contemporary studies have called for further empirical research into a number of related topics such as: the effects of consumer participation in virtual communities (J. Q. Dong and $\mathrm{Wu}, 2015$ ); how consumer marketing data from these communities can benefit marketers (Füller, 2016); and how the marketing implications of consumer empowerment signify a challenge for marketing strategists (Pires et al., 2006). It has become apparent that few research articles in the last decade have provided a comprehensive overview of the UCI literature from the perspective of how industry stakeholders are affected by the phenomenon. The few empirical investigations that have been carried out recently have focused on more specialised areas within UCI topics and have not developed wider theoretical perspectives of the UCI concept.

The aim of this paper is to address these outstanding gaps in the literature and contribute to this contemporary body of UCI research. We will achieve this by empirically exploring how distinct UCI marketing approaches are affecting the development of marketing and related management strategies for music industry stakeholders. The decision to focus this study on the intersection between UCI, marketing 
and other related aspects of industry stakeholder management strategies is supported by Verhoef et al. (2009: 38), who have proposed that 'future research should seek to understand what marketing and management strategies will optimize the brand customer experience interaction'. Other authors support this chosen research direction by acknowledging that marketing activities reflect the emergent influence of Internet and digital technologies on consumer behaviour (Akar and Topçu, 2011; Bampo et al., 2008; Mahajan and Venkatesh, 2000), especially in relation to user-centricity in the music industry (Gamble and Gilmore, 2013; Ho and Dempsey, 2010; Muñiz and Schau, 2007). Ultimately, this paper aims to make four substantial contributions to theory and practice in the interrelated fields of UCI, marketing and the music industry. First, through the fulfilment of its research questions, it will provide practical and pragmatic insights for industry practitioners on how different UCI marketing approaches are affecting their management strategies. Second, it will take steps towards answering many of the identified gaps in research and knowledge relating to the concept of UCI. Third, it will present theoretical models as a foundation for which new UCI marketing theory can be built upon. Last, it will offer directions for future research to advance our empirical findings.

The remainder of the paper is structured as follows. Firstly, a literature review of UCI from a marketing perspective is conducted, followed more specifically by user-centric marketing innovations within the music industry. Next, the research methodology of a three-stage qualitative empirical interview-based design is outlined and justified. In the succeeding section the results from the 52 interviews across the three interview stages and two stakeholder groups are presented and analytically discussed, relating the findings back to the key theories and viewpoints in the seminal literature. Lastly, the final section draws conclusions, highlights our theoretical contributions and proposes future research directions for the further development of UCI research in various industry/organisational contexts. 


\section{Literature review}

\section{User-centric innovation in the marketing domain}

Over the previous thirty years, the gradual assimilation of UCI into the marketing domain has resulted in numerous profound ramifications for user community development and types of innovative users, in addition to fundamental impacts of technology integration and influences on marketing strategies. The literature suggests that user communities are now considered a significant aspect of contemporary marketing (Casaló et al., 2008; Füller, 2016). There is evidence to suggest that communities are taking measures to ensure that their developmental processes are communicated and accepted by users (J. Q. Dong and $\mathrm{Wu}, 2015)$. There is also evidence that the provision of complementary product marketing expertise from consumers is translated into improvements in public perception and awareness of the product/service by the community (Agerfalk and Fitzgerald, 2008). Accordingly, the facilitation of user communities, especially those surrounding particular brands, is considered by many marketing practitioners to be both powerful and cost effective (Algesheimer et al., 2005). Arvidsson (2008) argues that this power is not necessarily limited to design and marketing decisions from the community; it can also result in the actualisation of material production outsourcing (if a product innovation) to the community. Some scholars advise that brand community building predominantly represents an effective marketing program because of its avoidance of media fragmentation and the cultivation of intense brand loyalty (Andersen et al., 2007; Füller, 2016). Other rationales provided in the literature include its application as a marketing media tool (Kim et al., 2008) or as an aggregator of consumer marketing data (Pitta and Fowler, 2005). Despite the clear importance of community-based UCI as a catalyst for innovative marketing strategies, it has been noted that there has been a lack of empirical research that has investigated various community aspects. These have included the perceptions of different industry stakeholders on the impact of the community on them and the associated development of a model of key influence processes (Rowley et al., 2007). These outstanding research gaps will be addressed by the 
current paper, by considering user communities as part of a larger study of how UCI is affecting heterogeneous industry stakeholders.

The literature has revealed some interesting insights into the distinct typologies of innovative users that now contribute - either directly or indirectly - towards the contemporary marketing domain (Pires et al., 2006). For instance, Berthon et al. (2007) discuss what they refer to as "creative consumers" who possess the aptitude and inclination to adapt and modify their products. They describe how this type of user represents both threats and opportunities for industry firms, who must develop proficiencies to monitor, control and collaborate with these users to discover innovation and marketing capabilities. Blazevic and Lievens (2008) suggest that, in some more extreme cases, industry firms come to institute consumers as "exchange partners" for combinative knowledge creation. However, the extent to which many users possess all of the necessary attributes required to be considered as an exchange partner has been subject to debate. For instance, Lettl and Gemunden (2005) discuss what they refer to as "inventive users", in which they exhibit idea creation competencies but lack other pre-requisite resources relating to finances, personnel and marketing. However, other scholars argue that so-called "lead users" have been known to demonstrate additional competencies in relation to aspects such as marketing and distribution (Gumusluoglu and Acur, 2016; Piller et al., 2012). Schreier and Prugl (2008: 29) also suggest that lead users can contribute significantly towards new product development because of their speed and intensity of adoption. They also call for further empirical research into "species" of innovative users to 'extend the knowledge on how to reclaim the territory of user innovation for innovation management and the marketing of new products'. Consequently, the current study will explore the type of innovative user that has manifested within our chosen industry context. It will also investigate how this innovative user group has influenced innovation management for stakeholders through their marketing and strategy channels. 
The impact of technology on UCI, and its associated connotations at diverse stages of the marketing mix, has become especially prevalent in the digital age, with the rise of more personal and interactive technological devices and platforms (Vargo and Lusch, 2004). At the early idea generation phase, Roser et al. (2009: 11) state that '[i]n a technology-enabled world of connected consumers, the consumer holds increasing knowhow.' Alternatively, in adherence with the theory of value co-creation, some academics have claimed that technological influences have incentivised marketers to cede production control to the consumers (Bonsu and Darmody, 2008; Prahalad and Ramaswamy, 2004). This viewpoint is advocated by Lettl and Gemunden (2005), who advise that inventive users are contingent on the external support of technological experts to transform their creative ideas into innovative products. Other scholars maintain that, although consumer empowerment at different stages may be enabled via technology in the current web-based economy, it is nevertheless delegated through business strategy (Pires et al., 2006). It has been alleged that the concept of technology as a facilitator for customercentricity has been largely overlooked in research and theory development (Wagner and Majchrzak, 2007). Therefore, the current study will consider the kinds of technological platforms and devices used in conjunction with UCI activities in the chosen industry setting. It will also consider how this is ultimately affecting business strategies for industry stakeholders.

The impact of UCI on organisational marketing strategies has received general and often fragmented discussion in the management literature (see Agerfalk and Fitzgerald, 2008; Bagozzi and Dholakia, 2006; Roser et al., 2013). For instance, Algesheimer et al. (2005) have written that, from a marketing perspective, the intentions of brand community users are to: (a) continue their membership; (b) endorse the community to non-members; and (c) actively participate in the community. They argue that the ultimate goal of the community is to generate an operative marketing program. More specifically, they suggest that these behavioural intentions may assist marketing managers with framing and communicating the community's influence on their consumers in familiar terms. Alternatively, 
Arvidsson (2008: 327) argues that, over the past several decades, consumer co-production has driven marketing to 'look actively for the productive potential of ordinary consumers'. He also states that this has involved embodying a cyclical relationship of discovery between the users and marketers that did not previously exist. Elsewhere in the literature, it has been noted that, in accordance with servicedominant logic theory, customer value co-creation is vital for marketing success. This is arguably on account of the users contributing towards the marketing process, thus accentuating the paradigmatic shift from value added to value co-creation (B. Dong et al., 2008; Lusch and Vargo, 2006; Vargo and Lusch, 2004). Other scholars have mentioned that the provision of innovation by end-consumers has the potential to be utilised for marketing purposes (Kleemann et al., 2008). Consequently, according to Roser et al. (2009: 11), '[c]o-creation also represents a new trend in innovation practice, marketing innovation and customer relationship management'. Some academics offer more in-depth commentary on how a more customer-centric organisational structure may necessitate a more expansive marketing function and the transfer of marketing resource management to a "customer manager" (D. Shah et al., 2006). However, it is still predominantly unknown exactly how or in what capacity user-provided innovations or cocreation can be implemented into marketing and management strategies.

The above discussion reveals a distinct lack of cohesion in the current literature on how different types of UCI are affecting marketing strategies from the context of specific stakeholders and a specific industry. It is also not especially evident in the existing literature as to the implications of these adapted marketing practices on other related management strategies of the affected stakeholders. Only by conducting a more robust and holistic empirical exploration on marketing-related UCI can we seek to instigate a richer understanding of these management domains and advance stronger theoretical fundamentals. Accordingly, the current study will undertake this endeavour from the context of the music industry, in which instances of UCI and innovative marketing practices are ubiquitous but, unfortunately, 
under-researched. The next section will explore the literature on what we know about user-centric marketing innovations in the music industry.

\section{User-centric marketing innovations within the music industry}

A review of the contemporary marketing literature indicates that marketing approaches and strategies within the music industry have endured radical and systemic shifts in the digital age (Kunze and Mai, 2007; Oestreicher and Kuzma, 2009). Music artists - whether established or up-and-coming - now use social media platforms to facilitate both self-marketing and distribution-based artist-driven strategies directly with their fans. This move is generally considered to be profitable on account of web traffic monetisation of advert placement and digital downloads (Antin and Earp, 2010). Undoubtedly, this development is closely correlated with the substantial loss of marketing governance from record labels, as the Internet age has afforded alternative distribution mechanisms (Karubian, 2008). In the post-Napster age in which the criminalisation of file-sharing networks (and in some cases the fans) by the major record labels is still a recent memory in the collective consciousness of the industry, free Internet access to artists' music is now generally accepted as good marketing practice (Nill and Geipel Jnr, 2010). As the notion of the "experience economy" has gained acceptance in the new millennium, this has also arguably resulted in a paradigm shift of industry-driven marketing strategies in the music industry. This is indubitably due to the increased range and volume of entertainment commodities (Beaven and Laws, 2007). The modern music consumer has become increasingly integrated into this experience economy of music through the proliferation of interactive digital platforms, devices and innovations of today's technologically-oriented society. Thus, the phenomenon of innovations centred around, or in some cases driven by, end-users in the music industry has been progressively important for its future development.

There is a clear significance of industry-driven marketing strategies from the most influential stakeholders within the music industry as discussed above. Despite this, however, the management 
literature provides virtually no insights into how consumers can be involved with, and contribute to, music marketing strategies that are instigated by industry stakeholders such as major record labels and global marketing companies. One isolated study by Oh and Park (2012) states that music-based social networking sites such as YouTube enable users to virally forward music content such as music videos to other Internet users, or to link these videos to other social networks. In doing so, they essentially become the unofficial online marketing team for the respective music artist. Further, in an exploration of userdriven marketing strategies in the form of user-generated media (UGM), Shao (2009) suggests that the appeal of such engagement by users is best examined through uses and gratifications theory, which relates to the psychological needs of the individual. Building on the work of Katz et al (1973), Shao identifies three sets of motivations for the user engagement: consuming - for information and entertainment; participating - for social interaction and community development; and producing - for self-expression and self-actualisation. From the industry stakeholder perspective, the motivations of managers to engage with social media and how it is influenced by personality traits is another significant factor for consideration. Rydén et al. (2015) address this point through an empirical investigation that presents four mental models of business-customer interactions. This was conducted in order to inform how managers conceptualise and utilise social media. Although the clear importance of both consumer and industry motivations to engage in UCI activities is worthy of further investigation, it falls outside the domain of the current research study and should instead be advanced by future research.

The increase in awareness of available music due to information shared through social media channels is acknowledged by Garg et al. (2011), who suggest that this linkage will enhance the need for research to measure the extent of information diffusion and peer influence through these social media channels. An industry report by Mulligan (2011: 7) asserts that 'some artists persist in using social channels as broadcast vehicles rather than multidirectional conversations'. However, it is also acknowledged that the artists are becoming increasingly receptive to the value of engaging with fans 
through social media channels and the associated mutual benefits. Furthermore, Smith (2012) has documented an innovative e-commerce platform site that offered social networking elements. On this site, music artists sell their music, consumers buy and socially share the content and then the subsequent sales are divided between the artists and the fans. The utilisation of social networks also contributes towards user-centricity in the music industry in two key ways that will now be discussed - through the development of user communities (Antin and Earp, 2010; Oh and Park, 2012; Parmentier and Mangematin, 2014) and the dissemination of user-generated content (UGC) (Dewan and Ramaprasad, 2014; Dhar and Chang, 2009).

Firstly, the emergence of user communities for music fans is a phenomenon that has gradually emerged over time and now manifests as a user-driven marketing strategy. It can also be perceived as exemplifying how UCI is affecting industry marketing practices based on its influence on both the music consumers and the artists. For the artists, Antin and Earp (2010) have suggested that the bonds formed through the bi-directional interactions in these communities can encourage the artists to act more "prosocially'. However, others suggest that these pro-social behaviours also reflect the view that these communities represent an easily targetable and influential word-of-mouth promotional vehicle for artistdriven strategies, that transmit viral marketing messages relating to their music offering (Oestreicher and Kuzma, 2009). This viewpoint is supported by Oh and Park (2012: 393), who state that the music consumers who populate and maintain these online communities 'unknowingly provide the basis for a business platform by which adult music producers can reap windfall profits'.

Secondly, user contributions in the form of UGC can represent a significant user-driven marketing influence on industry stakeholder strategic operations - related to both marketing and nonmarketing. For example, Dhar and Chang (2009) conducted an empirical study into various forms of UGC on their ability to predict online music sales. Their results indicate that one particular form of UGC - blog chatter - exhibits a proportionate relationship between the number of blog posts on an album and 
the number of online album sales. An industry report by the Arts Council (2010) discusses the rise in music UGC from consumers and suggests that this phenomenon may be partly attributable to technological advances in handheld devices (e.g., smart phones). Furthermore, Pulvino (2012: 1) has expressed the view that, in the current music industry climate, a laissez-faire approach is inclined to serve a user community best. He also comments that the manager can 'let the community evolve and function on its own, while occasionally stepping in'. This view illustrates instances of communities that are structured and monitored by the industry, while creative control and freedom are still maintained by the users. Similarly, Mulligan (2011: 2) discusses user contributions to music production by stating that a 'natural extension of fan engagement is to bring fans into the creative process. This is Fan-Fuelled Creativity. Turning to fans for creative input is new and unfamiliar ground for many'. Mulligan subsequently proposes three distinct objectives for this fan-fuelled creativity: a) creativity; b) engagement and c) marketing, with the first referring specifically to user contributions to music production and the other two objectives referring to the forming of bonds and marketing strategies.

\section{Theoretical development}

The initial literature review on UCI above has revealed that some academics have offered provisional steps towards theoretical development through assessing some of the literature. For example, Greer and Lei (2012) evaluated a number of UCI articles from diverse specialities and from the perspective of how organisations engage in various kinds of cooperative efforts. On the other hand, Bogers et al. (2010) present their literature review from the context of user-innovators. The above review, from the context of the music industry, provides an insight into the limited theoretical debate into the effects - both positive and negative - of UCI relating to marketing in this industry from stakeholder perspectives. From our review, we propose a general research framework of three distinct UCI marketing approaches that have emerged within the music industry - user-driven, artist-driven and industry-driven. We have also 
revealed the need for further empirical studies to explore this predominately untapped research area. This was stated by Gamble and Gilmore (2013: 1882) in their conceptual paper on co-creational marketing practices within the music industry. They conclude that ' $[\mathrm{t}]$ his study could be used as a starting point for further empirical research into various aspects of future co-creational marketing campaigns. These aspects include new areas for investigation such as the hybrid implications which have been discussed but are still under-researched and would benefit from further primary research'. Accordingly, the first research question to be addressed in the study is:

RQ1: How is user/artist/industry-driven UCI marketing in the music industry affecting the marketing strategies within and across key stakeholder groups?

The limited discussion only serves to highlight the fact that it remains predominantly unknown how exactly these innovative and interrelated marketing approaches are having a positive or negative impact within and across the management strategies of key industry stakeholders. By taking a step back and presenting a fresh overview of UCI from a marketing context in terms of how it affects the development of organisational management strategies within a dynamic and evolving industry such as the music industry, a superior clarity and configuration of theory, knowledge and understanding may be realised. This approach could potentially initiate more focused and pertinent additional empirical research to concentrate on the critical issues and challenges that have hitherto been disregarded in the research. It could also result in an improved perception of UCI as a justifiable and essential management strategy for companies and not exclusively an academic exercise. It may consequently have repercussions at the industry and policy level. As a direct result, the current paper will also address the following research question: 
RQ2: What is the impact of user/artist/industry-driven UCI marketing on related management strategies within and across stakeholder groups?

\section{Research methodology}

\section{Methodological position and design}

As this study sought to develop theory that is rooted in the systematic gathering and analysis of data, the approach adopted was in adherence with the general methodology of a grounded theory approach (Fernandez, 2004; Glaser and Strauss, 2009; Strauss and Corbin, 1994; Strauss and Corbin, 1998). Specifically, we decided to adopt an interpretive, epistemological research methodology due to the exploratory and emergent nature of the phenomena under consideration, as consistent with the philosophical positions of other scholars (see Grant et al., 2012; Qu and Dumay, 2011). For instance, Allard-Poesi (2005) provided clarity on the ontological position of an interpretive epistemology by stating that it seeks to develop an objective social science of subjectivity. Other key academics have emphasised that interpretivism epitomises an ontological reality where knowledge is derived from socially constructed meanings or consciousness (Cardoso and Ramos, 2012; Rowlands, 2005), consistent with the interpretation of UCI. Harris (2000: 756) crystallises these paradigmatic anomalies by stating that the interpretative requirement is to "capture the complexity and subjectivity inherent within management thinking, in order to help build and refine theoretical propositions and to enrich findings'. Based on the above discussion points, we therefore concluded that, due to the exploratory and opinionbased nature of the research questions of the current study, an interpretive epistemology would be adopted.

Based on the interpretive and exploratory nature of the research area, we decided to adopt a multistage interview-based research method. Our unit of analysis was decided as the stakeholder groups within the music industry whose marketing-related strategies are being affected by UCI. This decision was 
consistent with other recent music industry studies (see Gamble et al., 2017), in which key industry players such as individual industry experts, artists (and their representative Artist Manager) and corporations (and their representative CEO/Director or Senior Manager) are considered viable and comparable stakeholder groups under this unit of analysis. This study - like most researching the music industry - was not geographically limited due to the social and online global reach of the industry (Chaney, 2012; Choi and Burnes, 2013; Gamble and Gilmore, 2013; Izvercian and Alina Seran, 2013; Power and Hallencreutz, 2007; Soriano et al., 2008; Warr and Goode, 2011). Therefore, candidates from around the world were considered suitable representatives for the study if they held a senior management position in their organisation (the vast majority were either the company CEO or Director). They were also deemed suitable if they had substantial relevant experience or knowledge in the field of the interview stage. The decision to interview both autonomous industry experts and company representatives was taken in order to enhance the richness of the data, as this facilitated an eclectic range of stakeholder-level viewpoints from key individuals who have liaised with - as well as simply working for - different music industry companies throughout their career. This dual approach was consistent with the unit of analysis of the study and contributed to gaining a deeper insight into how UCI is affecting the marketing strategies and other management strategies of key industry stakeholders. Moreover, in adherence with our global sampling nature, interviews were ultimately conducted with key stakeholders from different continents including Europe, Africa, Australia and North America. The exploratory nature of the research topic and the above discussion advocated the use of an appropriate level interview question structuring, in order to facilitate an organised design with probing and follow-up questions (Grant et al., 2012; Qu and Dumay, 2011; Solaimani et al., 2017). We therefore decided to adopt an interview design that is both semistructured and multiple-stage. Accordingly, the design was intended to include a large sample size in Stage One to gain a broad understanding of how UCI is affecting industry marketing-related strategies and identify key affected stakeholder groups. A smaller sample size was sought in Stage Two to gain a 
deeper understanding of how UCI is affecting the marketing-related strategies of these specific groups. Another small sample size of follow-up interviews in Stage Three was sought to triangulate and validate the findings from the first two interview stages (Solaimani et al., 2017).

A scoping exercise was conducted to identify potential interview candidates for the three interview stages. A range of scoping techniques was utilised including search engine keyword searches, LinkedIn networking and additional searches in online databases and portals. Eighty-eight potential Stage One interview candidates were identified and their contact details were documented. These candidates can be broadly demarcated into three categories: senior managers of music industry firms that offer UCI services to facilitate consumer involvement and contributions; industry professionals or academics who research or write on the phenomena of UCI in the music industry; and other individuals who have several year's industry experience in the field of music industry UCIs. A total of 52 interviews were conducted across the three interview stages, resulting in a total of 2,363 minutes of interview data and 461 pages of interview transcription. All interviews were conducted in 2014 and were face-to-face; UK-based interviews were conducted in person and international interviews were conducted via Skype.

Stage One of the interview design consisted of 34 interviews, resulting in 1,800 minutes of interview data and 339 pages of interview transcriptions. Interview duration ranged from 27 minutes to 84 minutes, with an average duration of 53 minutes. Transcription duration ranged from 7 pages to 14 pages, with an average duration of 10 pages. The analysis of the Stage One interview findings resulted in the identification of two industry stakeholder groups that necessitated more focused and in-depth study in Stage Two of the interviews. The first identified stakeholder group was independent music artists; we decided that artist managers would constitute the most appropriate choice for these interviews for two reasons. First, they work closely with their artists and therefore constitute a representative voice for expressing views on behalf of them. Second, some artists may be unwilling or unable to answer questions focused on the business and management aspect of the music industry. Artist managers possess sufficient 
industry knowledge and experience to generate high quality interview data from the questions. They also have a stake in the findings of this study because, according to Ramírez (2005), they require the artists' innovativeness, authenticity and style to succeed. The second stakeholder group was major record labels and would involve speaking with senior managers within these global corporations.

Stage Two provided more focused and in-depth study by conducting interviews with five representatives from each of the relevant industry stakeholder groups, based on issues that emerged from the Stage One interview data. This resulted in 348 minutes of interview data and 57 pages of interview transcriptions. Interview duration ranged from 28 minutes to 55 minutes, with an average duration of 35 minutes. Transcription duration ranged from 4 pages to 9 pages, with an average duration of 6 pages. Stage Three of the empirical research design consisted of follow-up interviews with a select few of the Stage One interviewees whose original views had been most relevant to both the two research questions of the study and the subsequent Stage Two statements. The purpose of this interview stage was therefore to inform them of Stage Two interviewee responses to their initial statements and to request further insights or clarification. The target candidates for this stage of the research were 10 of the Stage One interviewees. Although these interviewees were demarcated into UCI firm senior managers, UCI researchers/writers and other UCI experts in Stage One, this aspect was not consulted as a deciding factor in the selection of candidates for Stage Three. The final interview count for Stage Three was eight indepth interviews, resulting in 215 minutes of interview data and 65 pages of interview transcription. Interview duration ranged from 15 minutes to 41 minutes, with an average duration of 27 minutes. Transcription duration ranged from 5 pages to 12 pages, with an average duration of 8 pages.

\section{Data analysis}

At each stage of the interview process the interview framework included an analysis phase in which it was necessary to implement an arbitrarily defined analysis framework. Several analytical considerations 
were developed in accordance with the grounded theory nature of the study. The first related to which analysis approach to adopt. Knox (2003: 122) offered a distinction between inductive and deductive analytical approaches whilst simultaneously advocating the significance of the decision between the two approaches. He described an inductive approach as one in which 'you would collect data and develop theory as a result of your data analysis is paramount'. Due to the exploratory nature of the current study, as well as the fragmented and scarce knowledge surrounding the research questions, it was most appropriate to analyse the interview data using an inductive approach in order to develop theoretical foundations.

The second analytical consideration referred to the coding approach to be adopted. DeCuir-Gunby et al. (2011: 138) suggest three distinct coding approaches to analysis; these consist of theory-driven approaches, structural approaches and data-driven approaches. They argue that structural coding approaches are required when the analysis codes develop from a particular project's research goals or research questions. Whereas they propose that a theory-driven coding approach is necessitated when the codes are developed a priori from existing concepts or theories. They supplement this description by stating that ' $[\mathrm{t}]$ he development of theory-driven codes typically requires constant revisiting of theory, whereas data-driven and structural codes necessitate repeated examination of the raw data. Thus, code development is an iterative process'. As it was decided above that the analysis approach for the current study would be inductive and theory-building, this precluded the option of adopting a theory-driven coding approach. Furthermore, as the research aim and questions are guided by minimal previous research and literature discussion, the strict adherence of codes to these questions as akin to a structural coding approach may not prove to be the most logical choice for maximising high-quality analysis of the interview data. The data-driven approach proposed by DeCuir-Gunby et al. (2011), in which they describe the codes as emerging from the raw interview data, was therefore the most appropriate and efficient for this study. 
The third consideration was the analysis technique. Leech and Onwuegbuzie (2007) describe and compare seven distinct techniques for analysing data. Due to the exploratory and multi-faceted nature of the current study, as well as the anticipated richness of the interview data due to the scale and depth of the qualitative interviews, some of these techniques would therefore be unsuitable for this study. According to the views of Leech and Onwuegbuzie (2007), constant comparison analysis is utilised in order to discover underlying themes from research data. This appeared to initially adhere to the decisions made above to incorporate an inductive analysis approach and a data-driven coding approach. In terms of contextual application, this technique is especially applicable to qualitative research studies as it uses the entire data set and it was originally devised to analyse multiple-stage data. All of these contextual aspects were applicable to the current study. Therefore, we decided that constant comparison analysis was the analysis technique to be utilised in the three stages of this interview research design.

On account of the above methodological decisions, an inductive, data-driven, four-phase constant comparison analysis technique was conceived and implemented for the current study. This was operationalised by importing the transcriptions of the interview data as internal sources within NVivo 10 - the designated software package for the analysis phase of the research design. NVivo was chosen as it is widely considered the standard computer-aided qualitative data analysis software (CAQDAS) for analysing qualitative data (Bazeley and Jackson, 2013; Gibbs, 2002). This is especially the case when a constant comparison analysis is to be implemented (Leech and Onwuegbuzie, 2011). Each internal source was then opened in turn and read through NVivo, in order to facilitate the multi-level coding procedure. When all of the sources had been coded, a range of first order and second order nodes had been created. The four phases of our analysis framework are outlined below in Table 1.

\section{[Table 1 here]}




\section{Results and discussion}

The results from the 52 interviews across the three stages will now be presented and discussed. The findings will be structured into the various types of UCI marketing strategies that were introduced in the literature review section - namely user/community-driven, artist-driven and industry-driven. Each interviewee is expressed as a code in adherence to the anonymity that was guaranteed to the participants in the original interview request emails. Each code consists of a numeric ' $S$ ' value, to signify the interview stage, followed by two randomly assigned letters (e.g. S1KM).

\section{User/Community-driven UCI marketing strategies}

In the Stage Three interviews, S1SC claimed that a major label admitted to him that they are actively embracing fan-made YouTube videos and generating substantial revenue from them by 'adding ads and links back to the music.' Oh and Park (2012: 370) describe the 'theoretical relationship between the social media and the music industry', in which YouTube-based viral activities from fans essentially transform their role into an active, albeit unofficial, element of the artist's marketing strategy. Our findings reveal that the implications of this theoretical relationship are much more wide-ranging than this in terms of both stakeholders and management strategies. We now know that labels appreciate that the development of their own marketing strategies to facilitate UGC content via YouTube can also have positive auxiliary repercussions on the financial aspect of their management strategies. Regarding how the labels would benefit from involving themselves in consumer-driven marketing campaigns (CMCs), S1SC stated that ' $[\mathrm{t}]$ here are definitely better ideas and better execution of music, marketing and management outside of the labels.' As this point was not discussed in the literature, it is significant as it informs us of the potential broad implications of how CMCs can actually impact on label management strategies. This is both in terms of marketing / non-marketing approaches and of various stages of these strategic processes. Furthermore, S2MJ highlighted the knock-on implications from CMCs on label 
management strategies by emphasising the cost-efficiencies of consumer involvement as a result of "the cheapest possible marketing.' Alternatively, S2SK believed that CMCs would only prove beneficial - to both marketing and non-marketing strategies - for the major record labels in certain circumstances as 'they have a fan base who are willing to perform that for them.' S1SC also suggested that licensing and rights issues are holding back the labels from involving themselves more in CMCs. However, he insinuated that the labels may be involving themselves more than they admit to by describing 'stealth activity that happens at all levels'. He also expressed that CMCs can be more effective with a (perceived) lack of label involvement because 'it's a potentially beautiful organic thing'. These findings also address areas not covered in the literature and provide a key insight into how labels may be integrating surreptitious involvement in CMCs into their non-marketing strategies. This has been implemented as a means of circumventing the legal entanglements associated with overt involvement, with a view to engineering a more effective natural output as part of an overall marketing strategy. We can now see how UCI marketing is affecting their long-term innovation orientation through the strategic implementation of inconspicuous operational activities.

In the Stage Two interviews with the major record labels, one type of UCI marketing that was raised by several interviewees related to fan community activities. S2SA acknowledged that the power exerted by fan communities supersedes 'anything that we as a record label can spend on marketing.' This common theme reflects that which was expressed by S1AP and contradicts some of the other major label executives who suggested that their internal marketing campaigns surpassed any consumer-driven campaigns. The major label interviewee S2SA eventually conceded in his interview that CMCs from online fan communities are also a critical source of revenue generation. These insights contest the suggestion by Pulvino (2012) that the industry's laissez-faire approach towards community-based UCI activities serves the community best. We now know that, although the community users may derive various benefits themselves, their marketing-related UCI activities generate significantly greater value 
for stakeholders in terms of both superior marketing power and critical revenue - especially when initiated by the consumers. S2BF - a senior executive within the same major label as S2SA - appeared to advocate the benefits of major labels taking a reactive approach to fan community marketing activities. He provided an example within their own label of a fan community that emerged around one of their major artists. He described how it has profoundly affected their comprehension of relinquishing control of the conversation surrounding artists in order to simply shape and harness the conversation. In advancement of Rogers' (2003) diffusion of innovations theory regarding adoption decision factors for innovation, Di Gangi and Wasko (2009: 305) state that 'by inviting user innovation communities to participate in innovation processes [...], an organization may feel more pressure to follow community interests'. Our findings challenge this statement by theoretically demonstrating how user community power has instilled a strong correlation between a voluntary modified control outlook by the labels and an enhanced artist freedom over both marketing and non-marketing strategies.

As a summary of the above findings and discussion, Figure 1 below depicts the impact of userdriven UCI marketing on artist/label management strategies, with box highlights to indicate the common themes and arrows to indicate the direction of influence.

\section{[Figure 1 here]}

\section{Artist-driven UCI marketing strategies}

In the Stage One interviews, S1PE emphasised the strong links between crowdfunding and the marketing aspect of supporting an artist. He commented that 'if someone supports a project financially [...], I think they're going to be telling their friends'. Mulligan (2011:2) expressed that '[s]mart artists recognise the [...] benefits that deeper fan engagement brings to all of their increasingly diverse sources of income'.

Our findings expand on this statement by demonstrating that, with crowdfunding engagement, the 
implications transcend financial through to marketing strategies for artists. The majority of the other themes in relation to positive effects on artist marketing strategies were derived from artist-initiated schemes for fans to become involved through the marketing process itself. In the Stage Three interviews, S1SP asserted that fan involvement in marketing has helped many major artists become initially successful and that 'collaborations that ended up making them really famous were not instigated by the labels.' This common theme was reflected by S1LO who suggested that even well-known independent artists are having success with incentives for fans to get involved in the marketing of them - as he advised that 'you can't make it as personal through a label.' Karubian (2008) proposed two theories on how label influence and investment in artists is contingent on how the artist's career stage (new vs established) and supply/demand factors affect their negotiation leverage. Here, he also argues that the loss of marketing governance from labels with the rise of social media artist-driven UCI marketing has been attributable to technological factors in the form of alternative distribution mechanisms. Our findings refute this statement by demonstrating that it is the user necessity for relationship marketing that label marketing strategies have failed to capture. This represents a driving factor in the success of artist marketing strategies that incentivise user involvement. However, the overall outcome of this scenario may still essentially benefit label marketing strategies, as they do not need to be reconfigured for fan involvement due to the proactivity of artists to assume this transformational marketing approach.

Many of the interviewees provided insights into the marketing caveats for artists when they encourage different types of UCI marketing integration into their management strategies. S1EA postulated that UCI in the marketing of artists is 'the place where it's easiest to make it very corny.' Moreover, S1DM commented on the limitations by stating that 'it will be part of it, but an artist's new record will not be marketed by the fans.' In terms of the rationale for this, S1EA argued that consumers becoming involved in marketing the artist through social media doesn't yet guarantee revenue. However, he did concede that it is where 'a lot of the loyalty is generated', a common theme that was reiterated by 
S2LP. These points are significant as they challenge the views of Antin and Earp (2010) who, drawing on theories of reciprocal altruism (Trivers, 1971), argue that artist-driven user marketing campaigns via social media assure profitability through advert and download monetisation. Conversely, we theorise from our findings that non-marketing aspects relating to the lack of guaranteed revenue from social media fan-driven artist marketing not only lead to artist marketing limitations of new releases, but also to strategic marketing opportunities for artists to generate loyalty and ticket sales.

S1MA suggested that some viral marketing campaigns created by the artists can be perceived as 'insincere and obviously commercial'. However, he conceded that sincerity may not be an issue in future due to the proliferation of viral channels to market music artists. These insights adhere to the suggestion by Beaven and Laws (2007) that the increase in entertainment commodities in the experience economy, combined with more independent music fan behaviour, has resulted in paradigmatic shifts in music industry marketing strategies. This statement reflects musicological reception theory which, according to Beaven and Laws (2007: 122), 'provides a framework for understanding the social and cultural roles that music may assume post-composition'. However, our findings advance this statement by demonstrating indications of a longitudinal progression from negative to positive strategic marketing implications for artists. This is implemented as their marketing strategies adapt to the ubiquity of viral entertainment platforms. This common theme was also echoed by S1SW, who suggested that involving consumers in artist marketing will counteract issues with insincerity as it shows "where a campaign is based on facts'. However, the proliferation of viral channels, combined with the resultant development of interesting user-infused content and experiences as advised by S1EA, may lead to its own challenges relating to message lucidity. S1FJ stated that the ease of fan-driven marketing via social media channels is somewhat offset by the drawbacks of the message getting 'watered down'. He suggested that this development is due to the saturation of viral online content and also stated that personal recommendations will always have a greater impact. Mulligan (2011) has stated that some artists fail to take full advantage 
of social media channels as multi-directional conversations with the consumers. Our findings theorise that the real issue is not that communications are unilateral, but rather that communication is too uninhibited and transformational. We now know that the ease and proliferation of viral marketing with the fans may arguably result in a lack of marketing message coherence for the artist. It may also result in user lethargy towards more engaged involvement in industry UCI practices. In the Stage Two interviews, S2SS stated that "[i]t takes less for them to write a tweet or press a button on Facebook of where their favourite artist is playing versus trying to actually organise that event.' However, a common theme that emerged from several interviews was that marketing represents the greatest opportunity on account of data-driven indirect involvement. S2SS stated that 'you can analyse the data that's already available to you without explicitly asking a question to your consumers.' S2MS also suggested that the Internet can be used to drive more coordinated consumer promotion, especially in the short term. Even though these points have not been covered in the literature, we now understand that a corollary of this low-involvement social media marketing from the fans towards the artists translates into label marketing enhancements, in addition to coordination, through their utilisation of non-invasive data analytics.

As a summary of the above findings and discussion, Figure 2 below depicts the impact of artistdriven UCI marketing on artist/label management strategies, with box highlights to indicate the common themes and arrows to indicate the direction of influence.

\section{[Figure 2 here]}

\section{Industry-driven UCI marketing strategies}

The topic of industry-driven UCI marketing strategies by the major labels in the music industry has been virtually neglected in the literature to date; thus our findings may represent new research ground for theoretical development. In the Stage One interviews, S1MA stated that the increase in consumer 
involvement in the marketing side of the industry will inspire record labels to find 'new ways to spread awareness of artists and get consumers interacting.' This common theme was reflected by S1LO who suggested that labels sometimes initiate new interactive experiences between consumers and artists. This theme is significant because it demonstrates how the major labels are receptive to inspiration involving the outsourcing of innovation to the other stakeholder group of artists. This has arguably resulted in a restructured marketing strategy for the artists that facilitates enhanced artist-fan interactions. In terms of the rationale for the openness of the major labels towards UCI outsourcing to the artists, S1GF stated that 'labels are starting to cotton on to this because they know the power of [...] social networking.' He also suggested that they already receive analytics from several services regarding user consumption patterns via social media channels. This is a common theme that was independently reiterated by S1SC when discussing how the labels 'often work with outside marketing firms and little groups. They're kind of fed new ideas.' We now know that UCI is driving the marketing strategies of the major labels to become more amenable to intelligence input, as they incorporate outside expertise from social media analytics and marketing firm idea generation. This, in turn, is guiding them towards more outsourced marketing outputs as they facilitate expansive and direct marketing interactions between the artists and users.

However, several interviewees across the interview stages maintained that the labels are still predominantly reluctant to adopt more open marketing strategies due to arrogance surrounding their perceived marketing abilities and the persistence of control retention measures. S1PE indicated that the major record labels are fundamentally opposed to UCI that markets the artists because of the associated control relinquishing implications. He predicted that ' $[\mathrm{t}]$ hey're going to be really slow to embrace it'. In the Stage Two interviews with the senior executives from the major record labels, the viewpoints by S1PE appeared to be validated by two of the interviewees, although they did not explicitly cite the control issue as a rationale. Instead, the common theme of superiority perceptions emerged. The major label 
representative S2SK argued for the superfluity of consumer involvement in their artist marketing. He expressed that their perceived superior marketing expertise negates the need for consumers because ' $[\mathrm{t}]$ here is some sort of marketing budget internally so such a crowd source campaign isn't really necessary.' Furthermore, S2BF emphasised the skill sets within resources that they possess by stating that 'world class marketing companies are looking at us to understand what we're doing.' These significant points have been made in the face of clear indications that the labels are occasionally exhibiting the foresight to acknowledge their innovation and marketing weaknesses. They have done this by leveraging the expertise and flexibility of other key stakeholders internal and external to their strategic operations. However, despite these admissions, we now know that the retained perception of the labels as monolithic and autocratic is perpetuated by their misplaced confidence in their contemporary marketing abilities. It is also advanced by other stakeholder prejudices derived from their ignorance of the labels' innovative experimentations. Regarding additional consequences of the labels' arguable superiority complex on their attitude towards UCI marketing strategies, S1MA proposed that internal label management are not 'incentivised to actually go and find the best consumer marketer.' He also suggested that, as a result, they might regard a CMC as 'more hassle than it's worth'. However, he also conceded that they would still benefit from involving themselves in these campaigns as 'they've done it before with street teams.' The evidence appears to suggest that major labels are gradually beginning to think more innovatively about how to harness consumer power. However, we now understand that the sheer scale of their resource infrastructure and enduring marketing pride still represent a duel barrier of disincentivisation and hegemony preservation. Inevitably, this must be overcome as part of their strategic marketing development.

Another prominent and common theme was that co-creation is useful to the major labels as part of a marketing campaign. S2BF highlighted the potential for co-creation relating to subsidiary activities such as product design. He stated that '[w]e've actually worked with super fans to help create the ideal 
product and then produced [it].' For S2SK, the use of co-creation for marketing activities can result in greater loyalty in certain genres because 'it is quite a cool little marketing thing'. Through these insights, we now know that the integration of co-creation into label marketing campaigns may have positive effects on artist marketing strategies. This is undoubtedly on account of enhanced fan loyalty, as well as positive effects on label non-marketing strategies through new product design outcomes. In the Stage Three interviews, S1MA expressed uncertainty about how much revenue is generated by these CMCs by commenting that 'it depends on how good the app is and whether the app is generated by advertisements.' He hypothesised that if these two conditions were met then potentially it could generate substantial revenue, although he cautioned about the ease of 'spending well over your budget.' Interestingly, the issues of revenue uncertainty and cost intensity were both independently reiterated by S1KM, who suggested that '[t]t's a bit like the old adage of where 'half the money I spend on advertising is a waste of money - I just don't know which half!' These findings demonstrate once more the reliance of outsourced expertise to the labels. They also prove how the uncertainty surrounding the revenue generation from these label-instigated marketing strategies brings both opportunities for financial success and challenges for budget control.

As a summary of the above findings and discussion, Figure 3 below depicts the impact of industry-driven UCI marketing on artist/label management strategies, with box highlights to indicate the common themes and arrows to indicate the direction of influence.

\section{[Figure 3 here]}

Our findings and discussion have presented new insights into UCI marketing within the music industry that challenge or advance the existing literature in relation to our chosen UCI marketing approaches, stakeholder groups and management strategies. Many of our findings, especially in relation to industry- 
driven UCI marketing strategies, cover topics not addressed in other studies and therefore may represent new research ground. We now present conclusions that make four contributions to theory and practice in the fields of UCI, marketing and the music industry.

\section{Practical contributions}

Our first contribution is, through the answering of our two research questions, to provide pragmatic insights for industry practitioners on how UCI marketing approaches are affecting their management strategies. Our first research question related to how distinct UCI marketing approaches in the music industry are affecting the marketing strategies within and across key stakeholder groups. For artist-driven UCI marketing approaches, we propose that label marketing strategies need not be reconstructed for fan involvement due to artist proclivity for this transformational marketing approach. Furthermore, we attest to the existence of evidence of a longitudinal progression from negative to positive strategic marketing consequences for artists, as their marketing strategies acclimatise to the proliferation of viral entertainment platforms. For industry-driven UCI marketing approaches, we conclude that the labels are infrequently displaying the foresight to recognise their innovation and marketing weaknesses. They are doing this by leveraging the proficiency and flexibility of other key stakeholders internal and external to their strategic operations. However, despite this, the enduring perception of the labels as slow-moving and monocratic is disseminated by their misdirected self-assurance in their contemporary marketing aptitudes. It is also perpetuated by other stakeholder prejudgments resulting from their unfamiliarity with the labels' innovative experimentations. Additionally, we argue that the scale of label resource infrastructure and marketing pride still epitomise a duel barrier of incentive deficiencies and hegemony safeguarding. This must be surmounted as part of their strategic marketing development.

Our second research question related to the impact of UCI marketing approaches on related management strategies within and across stakeholder groups. For user-driven UCI management 
strategies, we argue that labels understand that the progression of their marketing strategies to facilitate UGC content via YouTube can also have positive secondary impacts on their financial strategies. There are also potential wide-ranging implications of how CMCs can actually affect label management strategies. This is both in terms of marketing and non-marketing approaches but also in terms of various stages of these strategic processes. For artist-driven UCI management strategies, we argue that, with crowdfunding engagement, the implications transcend non-marketing (financial) through to marketing strategies for artists. Furthermore, non-marketing facets relating to the lack of guaranteed revenue from social media fan-driven artist marketing result in artist marketing limitations of new releases. They also lead to strategic marketing opportunities for artists to facilitate loyalty and ticket sales. For industrydriven UCI management strategies, we conclude that the amalgamation of co-creation into label marketing campaigns may have positive effects on artist marketing strategies through improved fan loyalty. They may also have positive effects on label non-marketing strategies through new product design results. Furthermore, we confirm a reliance of external expertise to the labels, and how ambiguity surrounding the revenue generation from these label-initiated marketing strategies conveys opportunities for financial success, yet also challenges, for budget control.

\section{Theoretical contributions}

Our second contribution is to take steps towards answering many of the identified gaps in research and knowledge in contemporary UCI studies. Casaló et al. (2008) requested research into the impact of consumer activities within virtual communities. We argue that, in the music industry, community marketing-related UCI activities produce superior value for stakeholders than for the users. This is in terms of both marketing and revenue - especially when instigated by the consumers as opposed to the artists. We also conclude that user community power has inculcated a strong association between a voluntary adapted control outlook by the labels and a heightened artist freedom over marketing (as well 
as non-marketing) career areas. Pires et al. (2006) called for research into how the marketing effects of user empowerment denote a challenge for marketing practitioners. We conclude that, for music industry stakeholders, the multi-directional marketing communication with users through social networks is too unstructured and transformational. The affluence and propagation of viral marketing with the fans may result in a lack of marketing message lucidity for the artist. It may also lead to user weariness towards more engaged involvement in industry UCI practices. Pitta and Fowler (2005) requested research into how online user marketing data can benefit marketers. We argue that, from a music industry context, low-involvement social media marketing from the fans towards artists can augment label marketing coordination, especially when they use non-invasive data analytics.

Our main contribution to theoretical development in the fields of UCI and marketing lie in the presentation of our three theoretical models in Figures 1-3. In these models we offer valuable insights, from the context of the music industry, into how user-driven, artist-driven and industry-driven UCI marketing approaches have had implications within and across the stakeholder groups, in terms of marketing-related management strategies. For example, with user-driven marketing activities, we conclude that labels may be assimilating furtive involvement in CMCs into their non-marketing strategies to evade the legal complexities of explicit involvement. This has been accomplished with a view to designing a more operative natural output as part of a holistic marketing strategy. Alternatively, with artist-driven marketing incentives for user involvement, we propose that it is the user need for relationship marketing that label marketing strategies have failed to encapsulate. This signifies a driving force in the accomplishment of artist marketing strategies that incentivise user involvement. Finally, with industry-driven marketing campaigns, we argue that the major labels are amenable to stimulation involving the outsourcing of innovation to artists. This has resulted in a streamlined artist marketing strategy that expedites enhanced artist-fan relations. These implications of different approaches to UCI marketing on the stakeholder groups and their related management strategies demonstrate the 
fundamentals of new theory development. The further exploration of these UCI theories would therefore benefit both practitioners and scholars in the fields of UCI and marketing in various industry contexts.

\section{Directions for future research}

Through our three theoretical models we have synthesised and consolidated the construction of these logical theoretical underpinnings in a way that could be used as a starting point for further research. In particular, future UCI researchers could explore and/or compare, through either qualitative or quantitative means, how UCI marketing is affecting other industries, sectors and/or stakeholder groups.

Our decision to focus this study solely on the music industry, which we acknowledge as a limitation, nevertheless creates the opportunity for future studies to compare the results with other relatable entertainment industry sectors that have been affected by UCI, such as the video games industry (Goltz et al., 2015). Future research could also take each of our theoretical models and conduct an in-depth investigation of that type of UCI driver. This could be conducted in terms of aspects such as motivations from user/industry perspectives or implications on other aspects of organisational strategies, business models or innovation processes. These studies could be carried out from the context of how the results generate value, revenue or other attributes for the associated stakeholders.

\section{References}

Agerfalk, Par J. and Fitzgerald, Brian, 2008, "Outsourcing to an unknown workforce: Exploring opensourcing as a global sourcing strategy". MIS quarterly,32(2):385-409.

Akar, Erkan and Topçu, Birol, 2011, "An examination of the factors influencing consumers' attitudes toward social media marketing". Journal of Internet Commerce,10(1):35-67.

Algesheimer, René, Dholakia, Utpal M. and Herrmann, Andreas, 2005, "The social influence of brand community: evidence from European car clubs". Journal of Marketing,69(3):19-34.

Allard-Poesi, Florence, 2005, "The paradox of sensemaking in organizational analysis". Organization, 12(2):169-196. 
Andersen, B., Kozul-Wright, R. and Kozul-Wright, Z., 2007, "Rents, rights n' rhythm: cooperation, conflict and capabilities in the music industry.". Industry \& Innovation,14(5):513-540.

Antin, J. and Earp, M., 2010, "With a little help from my friends: Self-interested and prosocial behavior on MySpace Music". Journal of the American Society for Information Science and Technology, 61(5):952-963.

Ardito, Lorenzo, Messeni Petruzzelli, Antonio and Albino, Vito, 2015, "From technological inventions to new products: A systematic review and research agenda of the main enabling factors". European Management Review,12(3):113-147.

Arts Council, 2010, "Digital Audiences - Engagement with Arts and Culture Online.": 1-65.

Arvidsson, Adam, 2008, "The ethical economy of customer coproduction". Journal of Macromarketing,28(4):326-338.

Bagozzi, Richard P. and Dholakia, Utpal M., 2006, "Antecedents and purchase consequences of customer participation in small group brand communities". International Journal of Research in Marketing,23(1):45-61.

Baldwin, Carliss, Hienerth, Christoph and von Hippel, Eric, 2006, "How user innovations become commercial products: A theoretical investigation and case study". Research Policy,35(9):1291-1313.

Bampo, Mauro, Ewing, Michael T., Mather, Dineli R., Stewart, David and Wallace, Mark, 2008, "The effects of the social structure of digital networks on viral marketing performance". Information Systems Research,19(3):273-290.

Bazeley, Patricia and Jackson, Kristi, ; 2013, Qualitative data analysis with NVivo. . London, Sage Publications Limited.

Beaven, Z. and Laws, C., 2007, "'Never let me down again' : loyal customer attitudes towards ticket distribution channels for live music events: a netnographic exploration of the US leg of the Depeche Mode 2005-2006 World Tour.". Managing Leisure,12(2/3):120-142.

Berthon, P., Pitt, Leyland F., McCarthy, I. and Kates, Steven M., 2007, "When customers get clever: Managerial approaches to dealing with creative consumers". Business Horizons,50(1):39-47.

Blazevic, Vera and Lievens, Annouk, 2008, "Managing innovation through customer coproduced knowledge in electronic services: An exploratory study". Journal of the Academy of Marketing Science,36(1):138-151.

Bogers, Marcel, Afuah, Allan and Bastian, Bettina, 2010, "Users as Innovators: A Review, Critique, and Future Research Directions". Journal of Management,36(4):857-875.

Bonsu, Samuel K. and Darmody, Aron, 2008, "Co-creating Second Life Market - Consumer Cooperation in Contemporary Economy". Journal of Macromarketing, 28(4):355-368. 
Brabham, Daren C., Ribisl, Kurt M., Kirchner, Thomas R. and Bernhardt, Jay M., 2014, "Crowdsourcing applications for public health". American Journal of Preventive Medicine,46(2):179187.

Cardoso, Ana and Ramos, Isabel, 2012, "Looking at the Past to Enrich the Future: A Reflection on Klein and Myers' Quality Criteria for Interpretive Research". Electronic Journal of Business Research Methods, 10(2):77-88.

Casaló, Luis V., Flavián, Carlos and Guinalíu, Miguel, 2008, "Promoting consumer's participation in virtual brand communities: A new paradigm in branding strategy". Journal of Marketing Communications, 14(1):19-36.

Chaney, Damien, 2012, "The music industry in the digital age: consumer participation in value creation.". International Journal of Arts Management,15(1):42-52.

Choi, Hwanho and Burnes, Bernard, 2013, "The internet and value co-creation: the case of the popular music industry". Prometheus,31(1):35-53.

DeCuir-Gunby, Jessica T., Marshall, Patricia L. and McCulloch, Allison W., 2011, "Developing and using a codebook for the analysis of interview data: An example from a professional development research project". Field Methods,23(2):136-155.

Desouza, Kevin C., Awazu, Yukika, Jha, Sanjeev, Dombrowski, Caroline, Papagari, Sridhar, Baloh, Peter and Kim, Jeffrey Y., 2008, "Customer-driven innovation". Research Technology Management,51(3):35-44.

Dewan, Sanjeev and Ramaprasad, Jui, 2014, "Social media, traditional media, and music sales". MIS Quarterly,38(1):101-121.

Dhar, V. and Chang, E., 2009, "Does chatter matter? The impact of user-generated content on music sales". Journal of Interactive Marketing,23(4):300-307.

Di Gangi, Paul M. and Wasko, Molly, 2009, "Steal my idea! Organizational adoption of user innovations from a user innovation community: A case study of Dell IdeaStorm". Decision Support Systems, $\mathbf{4 8}(1): 303-312$.

Dong, Beibei, Evans, Kenneth R. and Zou, Shaoming, 2008, "The effects of customer participation in co-created service recovery". Journal of the Academy of Marketing Science,36(1):123-137.

Dong, John Q. and Wu, Weifang, 2015, "Business value of social media technologies: Evidence from online user innovation communities". The Journal of Strategic Information Systems,24(2):113-127.

Edhlund, Bengt, ; 2011, Nvivo 9 Essentials. , Lulu.com.

Elo, Satu and Kyngäs, Helvi, 2008, "The qualitative content analysis process". Journal of advanced nursing,62(1):107-115. 
Enkel, Ellen, Kausch, Christoph and Gassmann, Oliver, 2005, "Managing the risk of customer integration". European Management Journal,23(2):203-213.

Faulkner, P. and Runde, J., 2009, "On the identity of technological objects and user innovations in function.". Academy of Management Review,34(3):442-462.

Fernandez, Walter, 2004, "Using the Glaserian approach in grounded studies of emerging business practices". Electronic Journal of Business Research Methods, 2(2):109-120.

Franke, Nikolaus, Schirg, Florian and Reinsberger, Kathrin, 2016, "The frequency of end-user innovation: A re-estimation of extant findings". Research Policy,45(8):1684-1689.

Füller, Johann, ; 2016, "The power of community brands-How user-generated brands emerge". In: D. Harhoff and K. R. Lakhani (eds.) Revolutionizing Innovation: Users, Communities and Open Innovation. Cambridge, Massachusetts: MIT Press. pp 353-376.

Füller, Johann, 2006, "Why consumers engage in virtual new product developments initiated by producers". Advances in Consumer Research,33(1):639-646.

Gamble, J. R., Brennan, M. and McAdam, R., 2016, "A contemporary and systematic literature review of user-centric innovation: a consumer perspective". International Journal of Innovation Management,20(1):1-45.

Gamble, J. R. and Gilmore, A., 2013, "A new era of consumer marketing? An application of cocreational marketing in the music industry.". European Journal of Marketing,47(11/12):1859-1888.

Gamble, Jordan R., Brennan, Michael and McAdam, Rodney, 2017, "A rewarding experience? Exploring how crowdfunding is affecting music industry business models". Journal of Business Research,70C:25-36.

Garg, Rajiv, Smith, Michael D. and Telang, Rahul, 2011, "Measuring Information Diffusion in an Online Community". Journal of Management Information Systems, 28(2):11-38.

Ghezzi, Antonio, Cortimiglia, Marcelo N. and Frank, Alejandro G., 2015, "Strategy and business model design in dynamic telecommunications industries: A study on Italian mobile network operators". Technological Forecasting and Social Change,90:346-354.

Gibbs, Graham R., ; 2002, Qualitative data analysis: Explorations with NVivo. . Milton Keynes, Open University Press.

Glaser, Barney G. and Strauss, Anselm L., ; 2009, The discovery of grounded theory: Strategies for qualitative research. . New Brunswick, USA, Transaction publishers.

Goltz, Nachshon, Franks, Jaimie and Goltz, Shem, 2015, "Changing the (video) game: Innovation, user satisfaction and copyrights in network market competition". Journal of Law, Technology and Public Policy,1(3):160-183. 
Grant, Matthew A., Rohr, Lia N. and Grant, J. T., 2012, "How Informants Answer Questions? Implications for Reflexivity". Field Methods,24(2):230-246.

Greer, Charles R. and Lei, David, 2012, "Collaborative innovation with customers: a review of the literature and suggestions for future research.". International Journal of Management Reviews, 14(1):63-84.

Gumusluoglu, Lale and Acur, Nuran, 2016, "Fit among business strategy, strategy formality, and dynamic capability development in new product development". European Management Review,13(2):107-123.

Harris, Simon, 2000, "Reconciling positive and interpretative international management research: a native category approach". International Business Review,9(6):755-770.

Hau, Yong S. and Kang, Minhyung, 2016, "Extending lead user theory to users' innovation-related knowledge sharing in the online user community: The mediating roles of social capital and perceived behavioral control". International Journal of Information Management,36(4):520-530.

Herstatt, Cornelius and Schweisfurth, Tim, 2014, "The intellectual pillars of user innovation: a cocitation analysis". Technologie- und Innovationsmanagement, Technische Universität HamburgHarburg Working Paper No. 87,(1):17.

Hienerth, Christoph, 2006, "The commercialization of user innovations: the development of the rodeo kayak industry". R\&D Management,36(3):273-294.

Hienerth, Christoph and Lettl, Christopher, 2011, "Exploring how peer communities enable lead user innovations to become standard equipment in the industry: community pull effects". Journal of Product Innovation Management,28(s1):175-195.

Ho, Jason Y. and Dempsey, Melanie, 2010, "Viral marketing: Motivations to forward online content". Journal of Business Research,63(9):1000-1006.

Hsieh, H. F. and Shannon, S. E., 2005, "Three approaches to qualitative content analysis". Qualitative health research, 15(9):1277-1288.

Izvercian, M., Seran, S. A., \& Buciuman, C. F., 2013, "Transforming usual consumers into prosumers with the help of intellectual capital collaboration for innovation". International Journal of Information and Education Technology, 3(3):388-392.

Janssen, Karen L. and Dankbaar, Ben, 2008, "Proactive involvement of consumers in innovation: Selecting appropriate techniques". International Journal of Innovation Management,12(03):511-541.

Jespersen, Kristina R. and Buck, Nuka, ; 2010, "Usage of ICT tools in new product development: creating user-involvement". In: L. Al-Hakim and C. Jin (eds.) Innovation in Business and 30 Enterprise: Technologies and Frameworks. New York: Business Science Reference. pp 76-90.

Karubian, S., 2008, "360 deals: An industry reaction to the devaluation of recorded music". Southern California Interdisciplinary Law Journal,18:395-462. 
Katz, Elihu, Haas, Hadassah and Gurevitch, Michael, 1973, "On the use of the mass media for important things". American Sociological Review,38(2):164-181.

Kim, Joong H., Bae, Zong-tae and Kang, Shim H., 2008, "The role of online brand community in new product development: case studies on digital product manufacturers in Korea". International Journal of Innovation Management,12(3):357-376.

Kleemann, Frank, Voß, G. G. and Rieder, Kerstin, 2008, "Un (der) paid Innovators: The Commercial Utiliza-tion of Consumer Work through Crowdsourcing". Science, Technology \& Innovation Studies,4(1):PP. 5-26.

Knox, Karl, 2003, "A Researcher's Dilemma-Philosophical and Methodological Pluralism". Electronic journal of business research methods, 2(2):145-154.

Konczal, John, 2008, "Identifying, knowing and retaining your customers: the "prosumer"'. Customer Interaction Solutions, 26(11):22-29.

Kunze, O. and Mai, L. W., 2007, "Consumer adoption of online music services: the influence of perceived risks and risk-relief strategies". International Journal of Retail \& Distribution Management,35(11):862-877.

Laursen, Keld and Salter, Ammon, 2006, "Open for innovation: the role of openness in explaining innovation performance among U.K. manufacturing firms". Strategic Management Journal,27(2):131150.

Leech, Nancy L. and Onwuegbuzie, Anthony J., 2011, "Beyond constant comparison qualitative data analysis: Using NVivo.". School Psychology Quarterly, 26(1):70-84.

Leech, Nancy L. and Onwuegbuzie, Anthony J., 2007, "An array of qualitative data analysis tools: A call for data analysis triangulation.". School Psychology Quarterly,22(4):557-584.

Lettl, Christopher and Gemünden, Hans G., 2005, "The entrepreneurial role of innovative users". Journal of Business \& Industrial Marketing,20(7):339-346.

Lusch, Robert F. and Vargo, Stephen L., 2006, "Service-dominant logic: Reactions, reflections and refinements". Marketing Theory,6(3):281-288.

Mahajan, Vijay and Venkatesh, R., 2000, "Marketing modeling for e-business". International Journal of Research in Marketing, 17(2):215-225.

Morrison, P. D., Roberts, J. H. and von Hippel, E., 2000, "Determinants of user innovation and innovation sharing in a local market.". Management Science,46(12):1513-1527.

Mulligan, M., 2011, "Agile music: Music formats and artist creativity in the age of media mass customization.": 1-12.

Muñiz, Jr, Albert M and Schau, Hope J., 2007, "Vigilante marketing and consumer-created communications". Journal of Advertising,36(3):35-50. 
Najmaei, Arash, 2014, "Towards an integrative model for management of organization's total innovation: insights from the strategic-process view". IUP Journal of Knowledge Management,12(3):61-73.

Nill, Alexander and Geipel Jnr, Andreas, 2010, "Sharing and owning of musical works : copyright protection from a societal perspective". Journal of Macromarketing,30(1):33-49.

Norman, Donald A. and Verganti, Roberto, 2014, "Incremental and radical innovation: Design research vs. technology and meaning change". Design Issues,30(1):78-96.

O’Neill, Maureen, 2013, "The NVivo toolkit: How to apply NVivo in your PhD for research and publishing success". The NVivo Toolkit, http://research.usc.edu.au/vital/access/services/Download/usc:10650/SOURCE2. Date accessed 14 January 2018, 1-52.

Oestreicher, Klaus G. and Kuzma, Joanne, 2009, "The music industry \& its consumers: A potential divorce through technology and shifting market linkages?". Chinese Business Review,8(9):1-16.

Oh, I. and Park, G. S., 2012, "From B2C to B2B: selling Korean pop music in the age of new social media.". Korea Observer,43(3):365-397.

Parmentier, Guy and Mangematin, Vincent, 2014, "Orchestrating innovation with user communities in the creative industries". Technological Forecasting and Social Change,83(1):40-53.

Payne, Adrian, Storbacka, Kaj, Frow, Pennie and Knox, Simon, 2009, "Co-creating brands: diagnosing and designing the relationship experience". Journal of Business Research,62(3):379-389.

Piller, Frank, Ihl, Christoph and Vossen, Alexander, 2010, "A typology of customer co-creation in the innovation process". Available at SSRN 1732127 (working paper),:1-26.

Piller, Frank, Vossen, Alexander and Ihl, Christoph, 2012, "From social media to social product development: the impact of social media on co-creation of innovation". Die Unternehmung, 65(1):7-27.

Pires, Guilherme D., Stanton, John and Rita, Paulo, 2006, "The internet, consumer empowerment and marketing strategies". European Journal of Marketing,40(9/10):936-949.

Pitta, Dennis A. and Fowler, Danielle, 2005, "Internet community forums: an untapped resource for consumer marketers". Journal of Consumer Marketing,22(5):265-274.

Polit, DF and Beck, C., ; 2004, "Assessing data quality". In: D. Polit and C. Beck (eds.) Nursing Research: Principles and Methods. Philadelphia, USA: Lippincott Williams \& Wilkins. pp 413-447.

Power, Dominic and Hallencreutz, Daniel, 2007, "Competitiveness, Local Production Systems and Global Commodity Chains in the Music Industry: Entering the US Market". Regional Studies, 41(3):377-389.

Prahalad, Coimbatore K. and Ramaswamy, Venkat, 2004, "Co-creating unique value with customers". Strategy \& Leadership,32(3):4-9. 
Pulvino, R., "Beyond The Music - How Artists Create Communities"; http://www.hypebot.com/hypebot/2012/10/beyond-the-music-how-artists-create-

communities.html?utm_source=feedburner\&utm_medium=feed\&utm_campaign=Feed\%3A+typepad\% 2FDqMf+\%28hypebot\%29.

Qu, Sandy Q. and Dumay, John, 2011, "The qualitative research interview". Qualitative Research in Accounting and Management,8(3):238-264.

Ramírez, Rafael, 2005, "The aesthetics of cooperation". European Management Review,2(1):28-35.

Rogers, Everett M., ; 2003, Diffusion of innovations. . New York, Free Press.

Roser, Thorsten, DeFillippi, Robert and Samson, Alain, 2013, "Managing your co-creation mix: cocreation ventures in distinctive contexts". European business review,25(1):20-41.

Roser, Thorsten, Samson, Alain, Humphreys, Patrick and Cruz-Valdivieso, Eidi, 2009, "New pathways to value: Co-creating products by collaborating with customers": LSE Enterprise London, 122.

Rowlands, Bruce H., 2005, "Grounded in practice: using interpretive research to build theory". Electronic Journal of Business Research Methods,3(1):81-92.

Rowley, Jennifer, Kupiec-Teahan, Beata and Leeming, Edward, 2007, "Customer community and co-creation: a case study". Marketing Intelligence \& Planning,25(2):136-146.

Ryan, Gery W. and Bernard, H. R., 2003, "Techniques to identify themes". Field methods,15(1):85109.

Rydén, Pernille, Ringberg, Torsten and Wilke, Ricky, 2015, "How managers' shared mental models of business-customer interactions create different sensemaking of social media". Journal of Interactive Marketing,31:1-16.

Sawhney, M., Verona, G. and Prandelli, E., 2005, "Collaborating to create: The Internet as a platform for customer engagement in product innovation.". Journal of Interactive Marketing,19(4):417.

Schildhauer, Thomas and Voss, Hilger, ; 2014, "Open innovation and crowdsourcing in the sciences". In: S. Bartling and S. Friesike (eds.) Opening science: the evolving guide on how the Internet is changing research, collaboration and scholarly publishing: London, Springer., 255-269.

Schreier, Martin and Prügl, Reinhard, 2008, "Extending lead-user theory: antecedents and consequences of consumers' lead userness". Journal of Product Innovation Management, 25(4):331346.

Shah, Denish, Rust, Roland T., Parasuraman, Ananthanarayanan, Staelin, Richard and Day, George S., 2006, "The path to customer centricity". Journal of service research,9(2):113-124. 
Shah, S. K. and Tripsas, M., 2007, "The accidental entrepreneur: The emergent and collective process of user entrepreneurship.". Strategic Entrepreneurship Journal,1(1):123-140.

Shao, Guosong, 2009, "Understanding the appeal of user-generated media: A uses and gratification perspective". Internet Research,19(1):7-25.

Sinfield, J. V., Calder, E., McConnell, B. and Colson, S., 2012, "How to Identify new business models.". MIT Sloan Management Review,53(2):85-90.

Smith, C., "Monkeybars Music Ecommerce Platform Splits Sales Between Artists And Fans"; http://www.hypebot.com/hypebot/2012/10/monkeybars.html?utm_source=feedburner\&utm_medium=f eed\&utm_campaign=Feed\%3A+typepad\%2FDqMf+\%28hypebot $\% 29$.

Solaimani, Sam, Heikkilä, Marikka and Bouwman, Harry, 2017, "Business model implementation within networked enterprises: A case study on a Finnish pharmaceutical project". European Management Review, 15(1):79-96.

Soriano, J., Lizcano, D., Hierro, J. J., Reyes, M., Schroth, C., \& Janner, T., 2008, "Enhancing user-service interaction through a global user-centric approach to SOA". In ICNS 2008, Fourth International Conference on Networking and Services. 16-21 March 2008, Gosier, Guadeloupe., 194203.

Strauss, Anselm and Corbin, Juliet, 1998, Basics of qualitative research: Techniques and procedures for developing grounded theory. Thousand Oaks, USA, Sage Publications, Inc.

Strauss, Anselm and Corbin, Juliet, 1994, "Grounded theory methodology". In: N. K. Denzin and V. S. Lincoln (eds.) Handbook of qualitative research. Thousand Oaks, CA: Sage. pp 273-285.

Trivers, Robert L., 1971, "The evolution of reciprocal altruism". The Quarterly Review of Biology, 46(1):35-57.

Vargo, Stephen L. and Lusch, Robert F., 2004, "Evolving to a new dominant logic for marketing". Journal of Marketing, 68(1):1-17.

Verhoef, Peter C., Lemon, Katherine N., Parasuraman, Ananthanarayanan, Roggeveen, Anne, Tsiros, Michael and Schlesinger, Leonard A., 2009, "Customer experience creation: Determinants, dynamics and management strategies". Journal of Retailing,85(1):31-41.

Von Hippel, Eric, 1976, "The dominant role of users in the scientific instrument innovation process". Research policy,5(3):212-239.

Wagner, Christian and Majchrzak, Ann, 2007, "Enabling customer-centricity using wikis and the wiki way". Journal of Management Information Systems,23(3):17-43.

Warr, Richard and Goode, Mark M., 2011, "Is the music industry stuck between rock and a hard place? The role of the Internet and three possible scenarios". Journal of Retailing and Consumer Services, 18(2):126-131. 
Wright, Christopher, Sturdy, Andrew and Wylie, Nick, 2012, "Management innovation through standardization: Consultants as standardizers of organizational practice". Research Policy,41(3):652662.

Zhang, Yan and Wildemuth, Barbara M., ; 2009, "Qualitative analysis of content". In: Barbara M. Wildemuth (ed.) Applications of social science research methods to questions in library and information science. Englewood, CO: Libraries Unlimited. pp 308-319.

Table 1. $\quad$ Four-phase constant comparison analysis framework

\begin{tabular}{ll}
\hline Phase & Description \\
\hline Phase & Reduction of raw interview data (DeCuir-Gunby et al., 2011); \\
One: & Creation of thematic categories (Edhlund, 2011) in order to provide aspects to \\
Category & describe, explain and/or compare (Ryan and Bernard, 2003); \\
Analysis & Writing up of category findings. \\
\hline Phase & Examining the category data from Phase One; \\
Two: & Theorising any obvious themes (Edhlund, 2011); \\
Thematic & Comparing the themes across data sources (DeCuir-Gunby et al., 2011); \\
Analysis & Rechecking coding consistency (Zhang and Wildemuth, 2009). \\
\hline Phase & Reiterative reading through the category data from phase one and thematic data \\
Three: & from phase two, in order to confirm the quality of the codes (DeCuir-Gunby et al., \\
Sub- & 2011); \\
thematic & Classification and coding of sub-themes; combining or organizing sub-themes into \\
Analysis & reduced numbers of categories (Hsieh and Shannon, 2005) and hierarchical \\
& constructions (O’Neill, 2013); \\
& Comparison of theme/sub-themes across data sources (DeCuir-Gunby et al., 2011); \\
& Rechecking of coding consistency (Zhang and Wildemuth, 2009). \\
\hline Phase & Summarising the associations between the data and results (Polit and Beck, 2004); \\
Four: & Evaluating the reliability via cross-referencing the data against the physiognomies \\
Reliability & of participants (Elo and Kyngäs, 2008) or the triangulation of data sources (Hsieh \\
Analysis & and Shannon, 2005); \\
& Writing up the findings; \\
& Achieving a balance between authorial text and authentic citations (Elo and \\
& Kyngäs, 2008); \\
& Relating the findings back to the literature; \\
& Drawing logical conclusions from the findings. \\
&
\end{tabular}




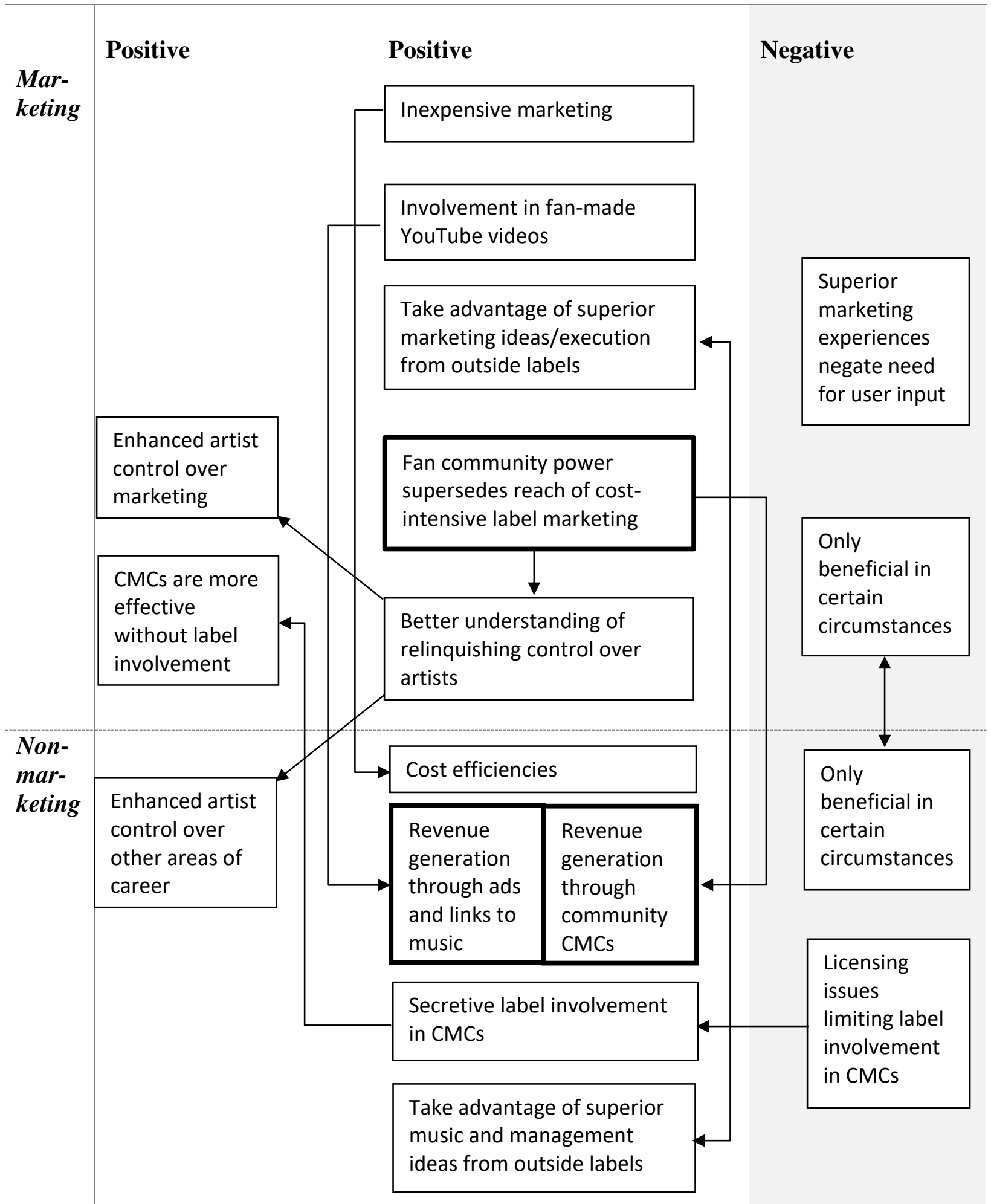

Figure 1. Impact of consumer-driven marketing campaigns (CMCs) on stakeholder management strategies 


\section{Artists}

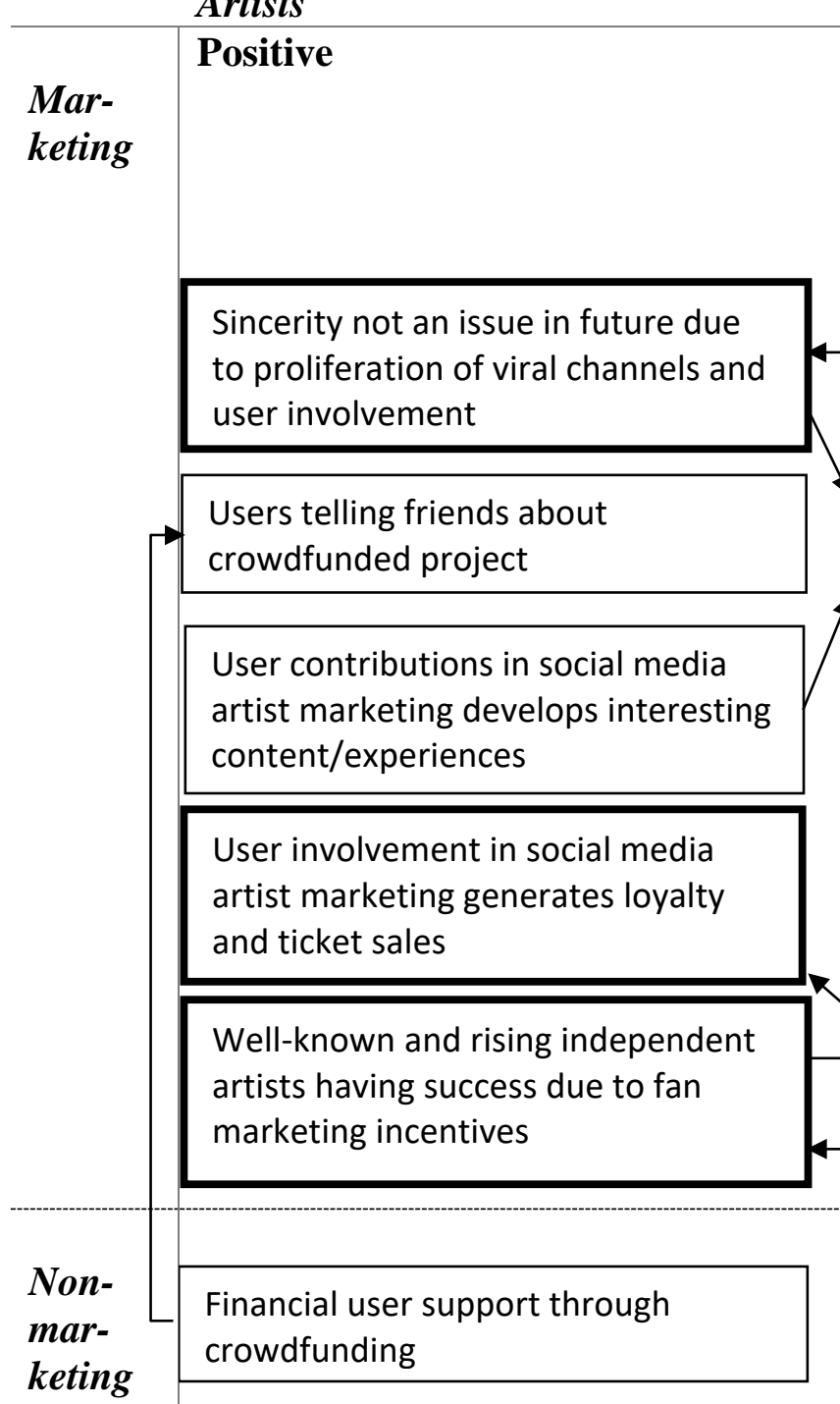

Labels

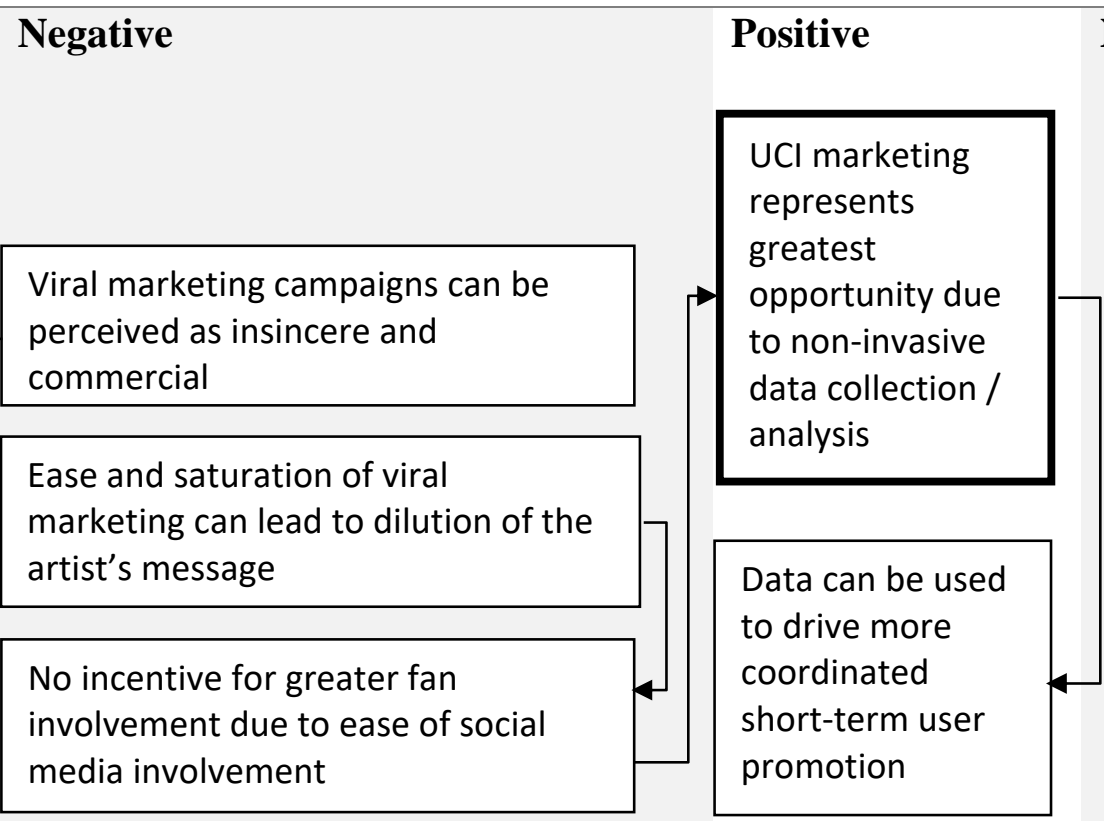

Fan marketing is inappropriate for an artist's new record

Labels don't need to initiate artistfan interactions due to artist proactivity

\section{Negative}
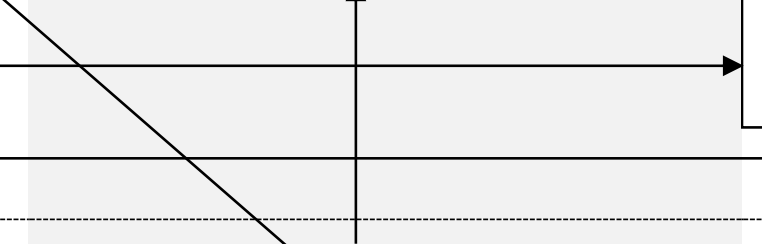

User involvement in social media artist marketing doesn't yet guarantee revenue
Fan marketing incentives are not as personal via a label

Figure 2. Impact of artist-driven UCI marketing on stakeholder management strategies 


\begin{tabular}{|c|c|c|c|}
\hline & Artists & Labels & \\
\hline \multirow{5}{*}{$\begin{array}{l}\text { Mar- } \\
\text { keting }\end{array}$} & \multirow[t]{3}{*}{ Positive } & Positive & Negative \\
\hline & & $\begin{array}{l}\text { Social media provide consumption } \\
\text { patterns to labels via analytics } \\
\text { services }\end{array}$ & $\begin{array}{l}\text { Labels are slow to embrace user } \\
\text { marketing involvement due to a } \\
\text { desire to retain control }\end{array}$ \\
\hline & & $\begin{array}{l}\text { Labels get new ideas on user } \\
\text { involvement from external marketing } \\
\text { firms }\end{array}$ & $\begin{array}{l}\text { Initiatives for user involvement in } \\
\text { marketing may be more hassle than } \\
\text { it's worth }\end{array}$ \\
\hline & $\begin{array}{l}\text { Increased interactions } \\
\text { with fans }\end{array}$ & $\begin{array}{l}\text { Labels inspired to find new ways for } \\
\text { fans to interact with artists }\end{array}$ & $\begin{array}{l}\text { Perceived superior resources and } \\
\text { marketing negate need for users }\end{array}$ \\
\hline & $\begin{array}{l}\text { Co-creation with labels } \\
\text { can result in greater } \\
\text { loyalty to artist }\end{array}$ & $\begin{array}{l}\text { Content co-creation is useful to } \\
\text { labels as part of a marketing } \\
\text { campaign }\end{array}$ & $\begin{array}{l}\text { No internal label incentivisation to } \\
\text { source the best user marketer }\end{array}$ \\
\hline \multirow[t]{2}{*}{$\begin{array}{l}\text { Non- } \\
\text { mar- } \\
\text { keting }\end{array}$} & & $\begin{array}{l}\text { Potential for co-creation to lead to } \\
\text { new product designs }\end{array}$ & $\begin{array}{l}\text { Revenue from consumer-driven } \\
\text { marketing is unknown as it depends } \\
\text { on app quality and advertising }\end{array}$ \\
\hline & & $\begin{array}{l}\text { Success with app quality/advertising } \\
\text { can lead to substantial revenue } \\
\text { generation }\end{array}$ & $\begin{array}{l}\text { Financial investment in app } \\
\text { quality/advertising can also lead to } \\
\text { budget over-spend }\end{array}$ \\
\hline
\end{tabular}

Figure 3. Impact of industry-driven UCI marketing on stakeholder management strategies 